\title{
WESTWERK, NYUGATI KÓRUS, NYUGATI KARZAT \\ (DR. ENTZ GÉZA PROFESSZOR GONDOLATMENETÉT FOLYTATVA ...)
}

\author{
DR. GUZSIK TAMÁS
}

Az építészettörténeti vizsgálatok során bizonyos témák időnként fölbukkannak, a közlést követően az eredményeket mindenki tudomásul veszi, néha évtizedekre eltünnek az érdeklődés homlokteréből, hogy aztán újból, esetleg új megközelítésben ismét rájuk terelődjön a figyelem. A jelek szerint ilyen, ciklikusan visszatérő kérdés a keresztény templomok nyugati terének vizsgálata. Mindenek előtt kötelességemnek tartom fölidézni, hogy ebben a témában a magyar szakirodalomban először Entz Géza professzor közölt összefoglaló és elemző munkát még 1959-ben. ${ }^{1}$ Húsz évvel később ugyanő visszatért a kérdésre, ${ }^{2}$ korábbi gondolatmenetét kiegészítve A. Tomasewsky 1974-ben publikált közép-európai tipológiai tapasztalataival. $^{3}$ Entz Géza munkáinak megállapításait jelen tanulmány szerzője teljes egészében elfogadja és magáévá teszi. A téma kutatásának gyarló és méltatlan folytatójaként - immár ismét két évtized elteltével - továbbfejlesztésként a vizsgálatot kiterjesztettem a Westwerk, a nyugati kórus (szentély), a nyugati karzat és nyugati előcsarnok összefüggéseire, időben és térben tágabb előképeire, valamint a különböző liturgikus cselekményekben betöltött szerepére.

A keresztény templomok vizsgálatánál a leggyakrabban a szorosan vett liturgikus tér, a szentély kialakításával szoktunk foglalkozni. A funkcionális különbözőségekből adódó apszis-formák alkalmasak tipológiai csoportosításra, esetenként az ott végzett egykori liturgia rekonstruálására. Ez az elemzési módszer annyiban jogos, hogy a keresztény templomokban a leggyakrabban végzett szertartás az Utolsó Vacsora emlékezete, a mise, melynek építészeti kerete, kiszolgáló tere a szentély. Jóval kevesebb figyelmet fordítunk a templom nyugati felének térképzé-

\footnotetext{
${ }^{1}$ Entz Géza: Nyugati karzatok románkori építészetünkben. Müvészettörténeti Értesítö 1959/2-3, 130-142. old.

${ }^{2}$ Entz Géza: Még egyszer a nyugati karzatokról. Építés- Építészettudomány 12, 1980, 133-141. old.

${ }^{3}$ A. Tomasewsky: Romańskie kościoly z emporami zachodnimi na obszarze Polski, Czech $i$ Wegier. Wroclaw-Warszawa-Kraków-Gdansk, 1974.
} 
sére, térkapcsolataira, holott ez is a liturgikus tér szerves része, s bizonyos szertartások színhelye lehet. A templomtengely kijelölése, az ún. keletelés, annak bonyolult szimbolikája egy külön tanulmány tárgyát képezi, ${ }^{4}$ így most csak az alapszimbólumra utalunk: a keleti (és a déli) oldal a „fény oldala” az életet, a feltámadást, általában a jót jelképezi, míg a nyugati (és északi) a „sötétség oldala”, mely a halál, a bün, és általában a rossz kifejezője. Több esetben éppen ez a meggondolás vezetett a nyugat-oldali szertartási helyszínhez. S itt ugyanúgy a megfelelő építészeti keretet ki kellett alakítani, mint a kelet-oldali apszisnál: vagy magán a templomon belül, vagy a templom nyugati oldalánál lévő önálló épületben.

A nyugati templomtérhez kötődő szertartások egy része már a keresztény liturgiák legkorábbi rétegében megtalálható. Az ősegyházban általános volt a katechumenatus, azaz a keresztelésre felkészítő idő, mely 2-3 év is lehetett. Ezalatt a hittanulók különböző fokozatok szerint tettek tanúbizonyságot felkészültségükről, s ennek alapján fokozatosan vehettek részt a közösség teljes istentiszteletén. Az új jelentkezők (flentes) csak a templomon kívül, a bejárat közelében tartózkodhattak, míg a már az első vizsgán (scrutinium) túljutottak (audientes) beléphettek a templomba, helyük a hátsó részben, a kapu közelében volt. Az ismert háztemplomokban (Dura Europosz, Qirqbiza), a korai szír (Nuriyeh, Rbé'ah, Kfer, Srir stb., IV. sz.) és az örmény (Tanahat, Dvin, Karnut, Garni, IV-V. sz.) templomoknál a templomtér hosszoldalához csatlakozó külső tornác szolgált a katechumenek tartózkodási helyéül. A hittanulók intézménye igazán Rómában virágzott a IV-V. században: a nagy bazilikák nyugati felében esetenként kettős előcsarnok épült (exo- és endonarthex), külön helyet biztosítva a két „osztály” tagjainak. Ugyancsak Rómában vált általánossá a nyilvános vezeklés intézménye a IV. századtól. A főbenjáró bünökért a püspök által kirótt vezeklés Húsvét előtt 40 nappal, az ún. Hamvazószerdán kezdődött, amikor a vezeklőket hamuval megszórva a diakónus kivezette a templomból az előcsarnokba. A böjt ideje alatt itt tartózkodtak, s csak Nagycsütörtökön fogadták vissza őket a gyülekezetbe. A szertartás szintén itt, a nyugati előcsarnokban folyt, míg a diakónus égő gyertyával visszavezette őket a szentély elé. A feloldozási liturgia legkorábbi szövege már a 430 körül keletkezett Sacramentarium Gelasianumban megtalálható. ${ }^{5}$ A további századokban keleten és nyugaton egyaránt építettek előcsarnokot a templomokhoz, függetlenül attól, hogy az eredeti funkciók részben megszüntek, részben módosultak. A bizánci szertartásrendben, a szerzetesi templomoknál a X. századtól új szerepet kapott az előcsarnok. A véglegesedett és terjedelmessé vált szerzetesi zsolozsmát, az imaórákat ${ }^{6}$

\footnotetext{
${ }^{4}$ Guzsik Tamás: A középkori keresztény templomok keletkezéséről. In: Holl A. - Mizser A. - Taracsák G. (szerk.): Csillagászati Évkönyv, 1997. Budapest, 1996. 180-191. old.

${ }^{5}$ Várnagy Antal: Liturgika. Abaliget, 1993. 384. old.

${ }^{6}$ Berki Feríz (szerk.): Az orthodox kereszténység. Budapest, 1975. 283-286. old.
} 
nem a templomban végezték, hanem erre a célra egy külön nagyméretű nyugati csarnokot hoztak létre (lité). Az építések időrendjét figyelembe véve az archetípus az athoszi Megiszté Lavra nyugati csarnoka (963), az elterjedés a XI-XII. századra tehető (Megara, Daphni, Sztirisz, Khiosz stb.). A bizánci szerzetesi szokás elterjedéseként az örmény kolostori templomokhoz is építettek hatalmas elöcsarnokot (gavit) a X. századtól (Szanahin, Haghbat, Geghard, Haghardzin stb.). Nyugaton is a szerzetesi intézményekkel van kapcsolatban az előcsarnok továbbfejlődése, de az előbbiektől eltérő módon. A többnyire a bencés szerzetesek által vezetett zarándoktemplomok főbejáratához építettek nagyméretű előteret (paradisum, galilea). Eredetileg a laikus szerzetesek helye volt az imaórák alatt (pl. Cluny II., 955-től, Paulinzella, 1102, Hirsau, 1082 stb.), a zarándok-funkció kiteljesedése során vált a templomba bejutni szándékozók várakozási, felkészülési helyévé (Tournus, 950-től, Cluny II., 955-981, Paray-le-Moniale, 1100 körül stb.). Egyes esetekben az elöcsarnok fölött emeleti kápolna is volt (St. Benoit-sur-Loire, 1060-tól), mely azonban a templomtérrel nem volt szerves kapcsolatban. Vézelay (1120-1132) zarándoktemplománál az előcsarnok keleti, templom felöli oldalán az előcsarnokba nyíló emeleti karzat épült, funkciója valószínúleg a zarándokok fogadásával, irányításával volt kapcsolatban.

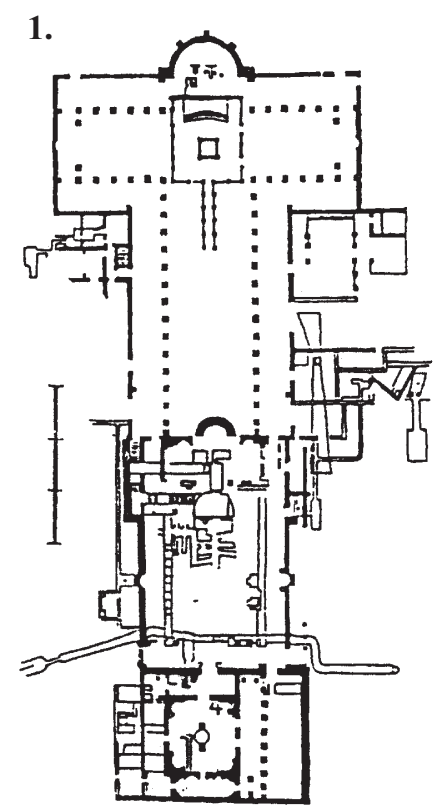

2.

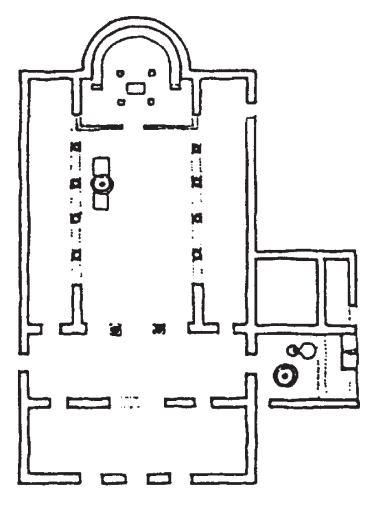

3.

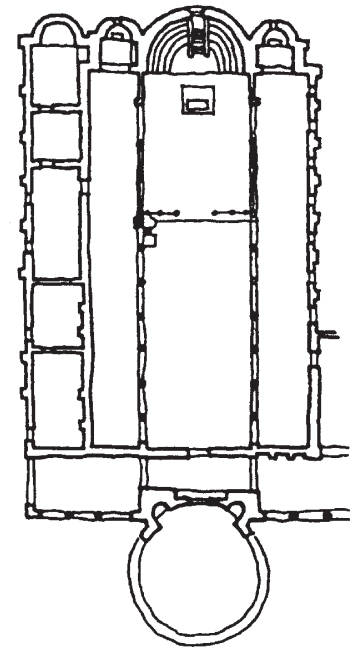

1. ábra. A templom nyugati oldalához épített baptisteriumok: 1. Abu Menasz, 2. Szunion, 3. Torcello 
A nyugati oldalhoz kötődő másik fontos funkció a keresztelés. Már az apostoli liturgiák első építészeti tereinél, a háztemplomoknál is igazolható, hogy a keresztelő-tér, a baptisterium az épület nyugati felében volt (1. ábra). A nyugati fejlődés során - elsősorban Itáliában - a baptisterium külön épületté vált a templom tengelyében, tôle nyugatra (Firenze, Pisa, Parma). Korai és egyedi példa Torcello (639től), ahol a baptisterium egybeépült a bazilikával, mintegy annak nyugati súlypontját kijelölve. Hasonló elrendezés a korai egyiptomi ókeresztény építészetre jellemző (Abu Menasz, 395-408, At-Mankabard, VII. sz.). A bizánci liturgikus tereknél szokásos, hogy a nyugati előcsarnokhoz délről csatlakozik a keresztelőkápolna, s a megkereszteltet a nyugati előcsarnokon keresztül vezetik be a templomba (Szunion, Szalona, Nikopolisz stb., V-VI. sz.). E hagyomány folytatásának tekinthető, hogy ahol nem épült külön baptisterium, ott a keresztelőkutat a nyugati elötérben helyezték el.

Ideológiailag rokon funkció a temetés ill. a halotti szertartás: a keresztségben a jelölt meghal a bünnek és újjászületik az életre, a halálban a testi halált váltja fel az örök élet, a feltámadás. A katakombai liturgiában szokás volt, hogy a keresztelést a vértanúk sírja mellett végezték, ennek gyakorlatát 578-ban szüntették meg. Mind a középkori sírok feltárása, mind az írott források bizonyítják, hogy a temetés is a keletelés szabálya szerint történt. Guillaume Durand (1230-1269) írta: , Miután a fejet nyugat felé helyezték el, a lábat kelet felé irányitják, amely helyzetben a halott mintegy maga mondja és helyesli, hogy kész arra, hogy a halálból a föltámadásba, a világból az örökkévalóságba siessen."7 A VII-VIII. századtól nyugaton kialakult az a gyakorlat, hogy a papokat, szerzeteseket a templom hajójában vagy a szentélyben (tehát a keleti részben) temették el, míg a világi jótevők (alapítók, donátorok) sírja a nyugati részbe került. Mind az élők, mind a holtak világában cezurát húztak a „megszentelt szféra” (klerikusok) és a „bünös szféra” (világiak) között, utóbbiak a templom „rossz” oldalán kaptak helyet. E téren változást csak a késő-középkor polgárosodó világa hozott, amikor a gazdag polgárok - a papokkal egyenrangúan - a szentélyben kaptak stallumot, majd sírhelyet (csarnokszentély). Addig azonban a nyugati templomrészben kellett nekik kiemelt helyet és sírhelyet biztosítani. A preromanika és a korai romanika szakrális építészetében létrejött egy olyan térforma, melyet ebbe a funkcióba is be lehetett vonni: ez volt a Westwerk.

A VII-VIII. századi nyugati, ún. gallikán liturgiákban jellegzetesen keveredett a római tanultságú térítő szerzetesek ,rómavárosi liturgiája” a népvándorlás-kori, még pogány népek helyi szokásaival, $\mathrm{s}$ a kereskedelem révén a nyugati területre került keleti (bizánci, szír, örmény stb.) diaspórák liturgikus hagyományaival. DélEurópában (Ravenna környéke, Veneto, Lombardia, Hispánia) jelentős szerepet

${ }^{7}$ Dölger: Sol Salutis. Münster i. W., 1925. 136. old. 
játszott a IV-V. században ariánus hitre tért gótok - a rómaitől némiképpen eltérő - szertartásrendje. A brit szigetek első térítői viszont jelentős észak-afrikai kapcsolatokkal rendelkeztek, liturgiájuk szintén jelentősen különbözött a rómavárositól. Mindezek a hatások hozták létre azt a sokarcú, hibrid liturgikus alakulatot, melyet gyüjtőnéven gallikán liturgiáknak nevezünk. ${ }^{8}$ Területenként különböznek (mozarab rítus Hispániában, ambrozián liturgia Milánó környékén, ó-gall, ó-ír stb. liturgiák), de közös jellemzőjük a keleti elemek átvétele, a lírai hangvételü himnuszok és magánimádságok a szertartási szövegekben, az „ábrázoló szimbólumok” alkalmazása a liturgia külsőségeiben és a templomépítésben. A legtöbb gallikán elemet a nagyheti szertartások őrizték meg az időközben egységesedő nyugati liturgiában - egészen a legutóbbi időig. Jézus szenvedése, kereszthalála és feltámadása, azaz a húsvéti ünnepkör fö mondanivalója szinte kínálta az alkalmat a szertartások „dramatizálására”, az ábrázoló szimbólumok széleskörű alkalmazására. ${ }^{9}$ A húsvéti szertartások egyik színhelye így a templom nyugati része („halál-oldal”) lett, s e célra önálló térrész alakult ki, a Westwerk. Virágvasárnapon, Jézus jeruzsálemi bevonulásának az emlékére pálmát (barkát) szenteltek ebben a térben, innen indult a körmenet, majd visszatérve ezen a kapun „kopogtatott” a diakónus, majd a körmenet bevonult a keleti szentélybe (Zsolt. 24,7-8.). Hasonló az örmény egyház virágvasárnapi szertartása. Nagycsütörtökön a föoltár terében ôrzött Oltáriszentséget elviszik egy külön kápolnába (pasztophorion), s ott őrzik a nagyszombati feltámadási szertartásig („,Jézus elrejtőzött a szemük elől” - Lk.4,30.). A szentségőrzés színhelye szintén a nyugati épületrészben volt, rendszerint az emeleten. Nagypénteken a Passio-olvasás esetenként dramatizált változatban történt a Westwerk emeleti tereiben, majd a „kereszthódolat” szertartásában (,,Ecce lignum crucis... ") magát a keresztre feszítést jelenítették meg, végül a ,sírbatétel” helyszíne, az úrkoporsó szintén itt kapott helyet. Nagyszombaton a tüzszentelés részben római hagyományú (lucernarium), részben ősi germán szokás (Ostara és Balduin istenek máglyája), részben az ír szerzetesek által 590-től bevezetett helyi liturgikus elem: a tüzet a templom nyugati kapujánál gyújtották, majd innen vitték a fényt a templom keleti felébe. A Nagycsütörtökön eltett Oltáriszentséget a feltámadási szertartás során vitték vissza az eredeti helyére, a föoltár terébe. Az úrkoporsóhoz kapcsolódott a később önálló szertartássá vált feltámadási körmenet is, szintén a nyugati térrészből indult. A nagypénteki és nagyszombati, a nyugati térrészben végzett szertartás máig él a bizánci liturgiában: Nagypénteken a templom nyugati részében egy szentsír-oltárt (epitáphion) állítanak, ide viszik el körmenetben az evangéliumos könyvet, itt végzik Nagyszombaton Szt. Vazul liturgiáját, végül Húsvét éjjel innen indul a föltámadási körmenet.

\footnotetext{
${ }^{8}$ Radó Polikárp: A megújuló istentisztelet. Budapest, 1973. 53-54. old.

${ }^{9}$ Szunyogh Xav. Ferenc (szerk.): Magyar-latin misszále. Budapest, 1933. 383-547. old.
} 
A bonyolult, és keleti elemekkel tarkított gallikán húsvéti szertartás tehát egy összetett teret igényelt a templom nyugati felében. Az építészeti kialakításban bizonyára előképként szolgált az ókeresztény bazilikák előcsarnoka is, de eredeti formájában alkalmatlan volt erre az új funkcióra. Ugyanakkor az ,ábrázoló jelképek" teljességéhez az is hozzátartozott, hogy az adott templom húsvéti eseményeinek színhelye valahogyan utaljon az eredeti helyszínre is. Ez is közrejátszott abban, hogy a középkor folyamán a legtöbbször másolt épület a jeruzsálemi Szent Sír templom, annak centrális-körüljárós anasztaszisz tere volt. Több egykorú forrás beszámol arról, hogy az építtető elküldte a megbízottját Jeruzsálembe a Szentsír méreteinek és formájának lemásolására (pl. Cambrai-ból Lietbert püspök 1060 körül, Meinwerk paderborni püspök 1160 körül, Péter remete Liége környékéről, 1096 stb.). ${ }^{10}$ A Karoling-kortól kezdve a IX-X. század során sorra épültek az önálló Szentsír-kápolnák, vagy a templom nyugati végéhez csatoltak egy centrális, toronyszerü, többszintes épületrészt. A német elnevezés, a „Westwerk” (= nyugati mú) a fordításokban nem adja vissza jól a térforma lényegét és jellegét, ezért a szakirodalomban legtöbbször fordítás nélkül a német elnevezést használják. Az elterjedésben egy további jelképi áttétel is szerepet játszott: Nagy Károly császár aacheni palotatemploma (790-806) önmagában is a jeruzsálemi anasztaszisz-teret kívánta jelképezni és másolni. A Westwerkek egy részénél a közvetett, jeruzsálemi analógia mellett közvetlen utalás is van a karoling központ, Aachen térformájára (pl. Essen, Münster, X-XI. sz., Dijon, Saint-Bénigne, 1001-1018 stb.). A kétféle jelképi tartalom összekapcsolásában annak van szerepe, hogy a Westwerk egyben a templom kegyúri családjának a magánkápolnája és temetőhelye is volt. Aachenben máig áll a templom karzatának nyugati oldalán Nagy Károly császári trónja, az uralkodó innen részt vehetett a templomban folyó istentiszteleten anélkül, hogy kiváltságos elkülönülését feladta volna. A Westwerk továbbélésének egyik formája, a nyugati (kegyúri) karzat ezt a funkciót őrizte meg. Azt már kevesebben szokták megfigyelni és megemlíteni, hogy az aacheni trónus mögött áll egy oltár, amely viszont az említett húsvéti szertartásoknál játszik szerepet (repositiós oltár) (2. ábra).

Nagyobb szerzetesi templomokban az aacheni példától független Westwerkkialakítás vált általánossá. Mintegy a keleti keresztházat és négyezeti tornyot tükrözve a nyugati oldalon is egy keresztház-szerü, középtornyos, lépcsőtornyokkal közrefogott többszintes építményt emeltek (pl. Centula, S. Riquier apátság, 790-799, Corvey, apátság, 855-885, Limburg a.d. Hardt, káptalani templom, 1025-1042, Quedlinburg, St. Servatius káptalani templom, 1070 körül, Paderborn, dóm, 1000 körül stb.) (3. ábra). Valamennyi példánál a földszint egy többhajós csarnok, melyben sírhelyek vannak és halotti szertartásokat végeztek benne. Az

10 Lásd Marosi E. (szerk.): A középkori müvészet világa. Budapest, 1969. 66-67. old. 


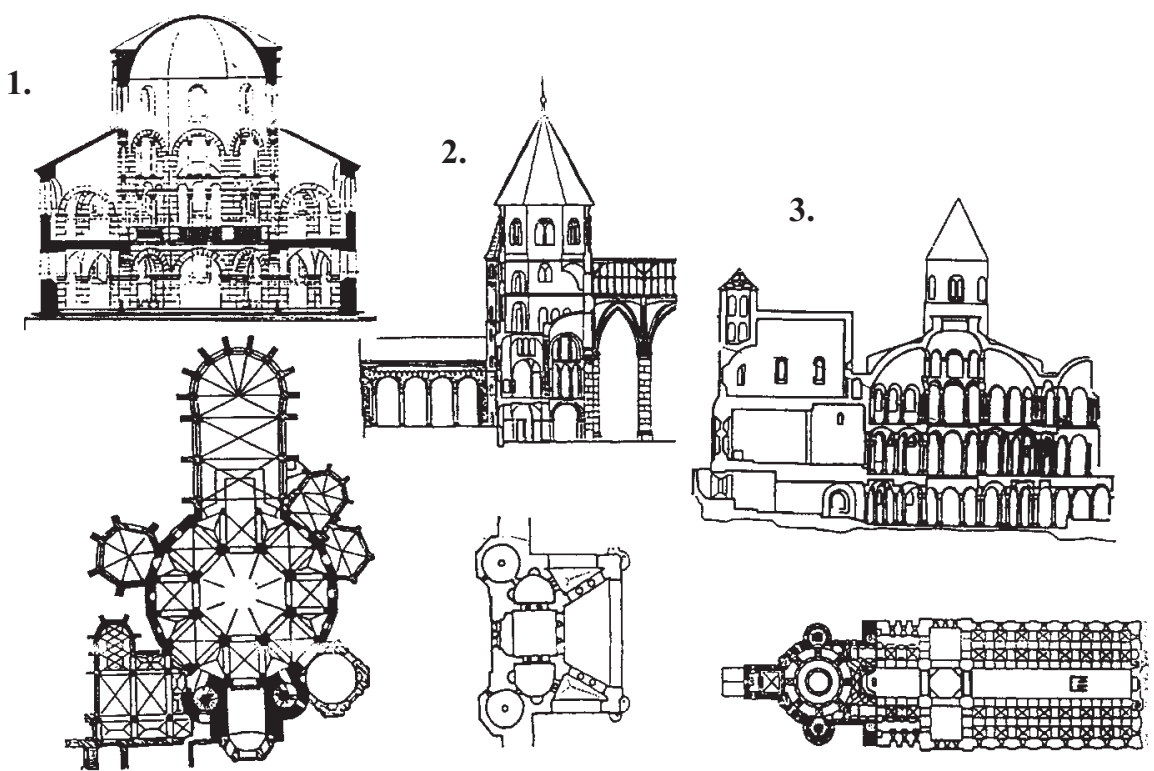

2. ábra. A jeruzsálemi Szent Sír templom Anasztaszisz terét idéző Westwerk-kompozíciók: 1. Aachen, palotatemplom, 2. Essen, Münster, 3. Dijon, S. Bénigne

emelet középrésze emelkedik ki toronyszerủen, itt van a húsvéti szertartások kápolnája és oltára. Ennek az emeleti kápolnának esetenként lehet külön nyugati karzata is a kegyúr számára (Centula, Corvey). Entz Géza az 1980-ban megjelent második tanulmányában - Heitz és Möbius elemzésére hivatkozva ${ }^{11}$ - az Angilbert által épített centulai Westwerk emeletén a „Megváltóról nevezett” kápolnát és a hozzá kapcsolódó triumfális körmenetet említi (húsvéti körmenet?). A közlésből az is kiderül, hogy a kegyúri funkciót ellátó császári magánkápolna (Sz. Mária kápolna) különálló épület volt, tehát a Westwerknek nem volt ilyen kegyúri feladata. Edgar Lehmann viszont Corvey megmaradt Westwerkjének vizsgálata kapcsán arra a következtetésre jut, hogy a krisztusi és a császári triumfálás színhelye egyaránt az apátság nyugati, toronyszerú építménye volt. ${ }^{12}$ Adott esetben a templom egyetlen nyugati tornya is betölthette a Westwerk-funkciót, erre a magyarországi példák kapcsán még visszatérünk. Az Entz által is idézett Saint Savin-surGartempe templomát (1060-1115) azonban itt kell vizsgálnunk. ${ }^{13}$ A torony emele-

11 Heitz, Carol: Recherches sur les rapports entre architecture et liturgie à l'époque carolingienne. Paris, 1963. 161. old., Möbius, F.: Zur Deutung des karolingischen Westwerks. Acta Historiae Artium 1968. 122-123. old.

12 Kunstchronik, 1964. 164-169. old.

13 Zodiaque, h. é. n., 24-25. old. 

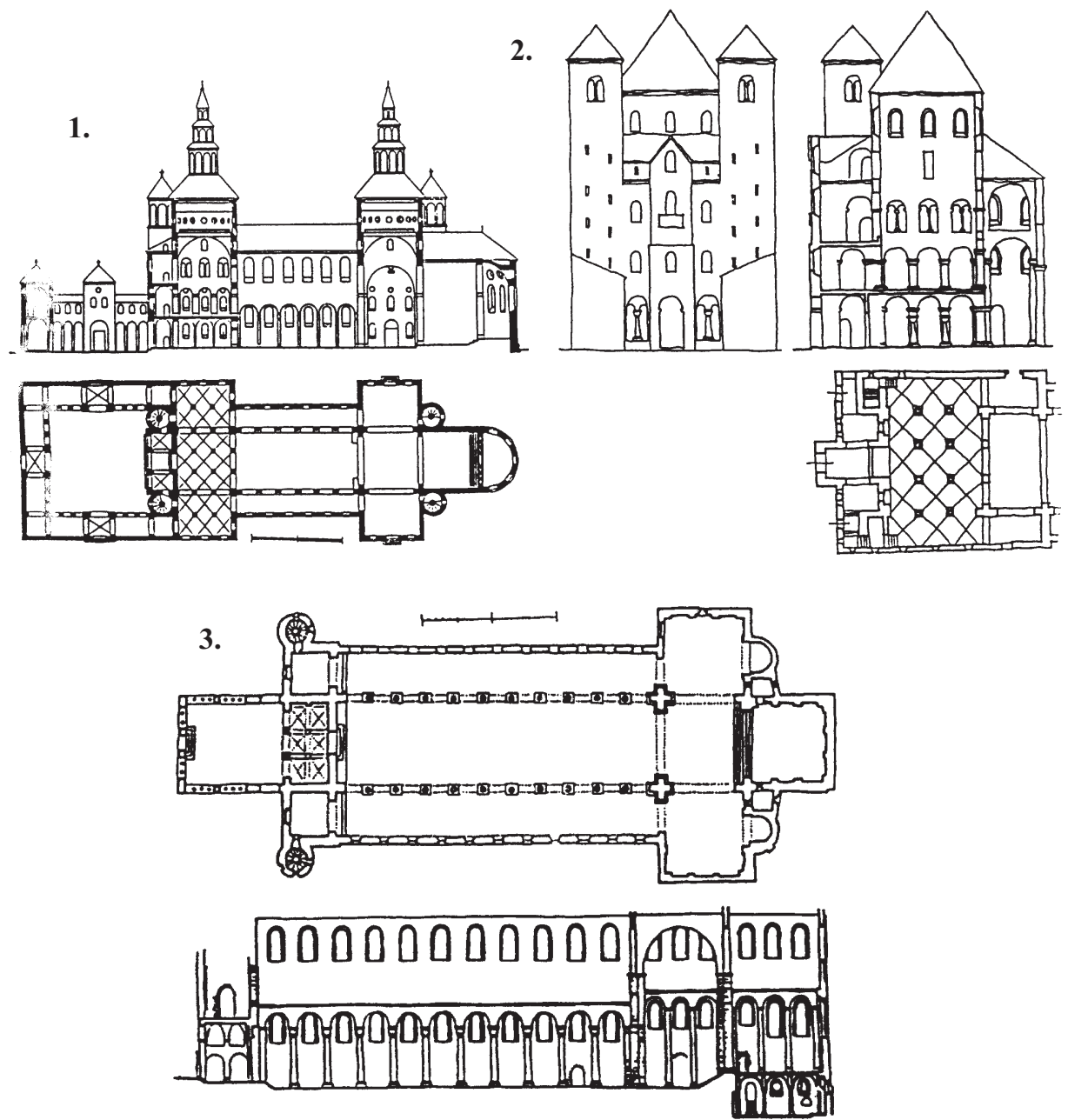

3. ábra. Karoling-kori Westwerk-formák: 1. Centula, S. Riquier, 2. Corvey, apátság,

3. Limburg a.d. Hardt, apátság

te széles ívvel nyílik a hajóba, s az egész templomra jellemző gazdag falfestés itt, a nyugati oldalon is szigorú ikonográfiai kötöttségeket tükröz. A helyiség falain a szenvedéstörténet jelenetei láthatók, míg a keleti, hajóba nyíló ívezetre a Maiestas Domini és az Agnus Dei képe került. Entz is megjegyzi, hogy „az ikonográfiai program a húsvéti ünnepkörben fogant", s azt sejteti (de konkrétan nem mondja ki), hogy ez az emeleti kápolna is a nagycsütörtök-nagyszombat közötti szertartások színhelye volt. Analógiaként a württembergi Schwäbisch Hall 1156-ban fölszentelt Szt. Mihály templomát, és annak nyugat-oldali Mária-Magdolna kápolná- 
ját említi - hasonló tartalmú falfestményekkel. Csak megemlítendő, hogy azon a kevés helyen, ahol ismerjük a Westwerkben lévő kápolna titulusát, ott az elnevezés vagy közvetlenül utal a húsvéti eseményekre és szertartásokra (Krisztus teste, Föltámadás, Szentsír, Szentkereszt stb.), vagy a halottkultusszal van kapcsolatban (Utolsó Ítélet, Föltámadás, Szt. Angyalok, Szt. Mihály stb.).

Hispániában a karoling típusok nem terjedtek el, az itt végzett mozarab liturgia viszont szintén igényelte a nyugati önálló térrészt. Itt rendszerint a főhajó nyugati végében alakították ki a többszintes Westwerket az emeleti kápolnával (pl. Naranco, S. Miguel de Lillo, S. Cristina de Lena, Valdedios templomai stb., IX-X. sz.). A templom nyugati oldalához kapcsolódó önálló szakrális tér nem volt ismeretlen a karoling-kor előtt sem. A nyugatról kapcsolódó baptisteriumokat már említettük akár Itáliában (Torcello), akár Egyiptomban (Abu Menasz). A halottkultusszal kapcsolatos ilyen térforma Rómában a SS. Marcellino e Pietro bazilika, melynek nyugati oldalához épült Szt. Ilona mauzóleuma (IV. sz. közepe). De az összetett rendeltetésű (halottkultusz, húsvéti szertartás, kegyúri funkció) nyugati építmény, a Westwerk jellegzetesen a gallikán liturgiák terméke (4. ábra).

Ellentmondásnak tünik, hogy ez a gallikán forma éppen a karoling-korban teljesedett ki. Nagy Károly ugyanis a birodalmában a liturgiát is egységesíteni akarta,
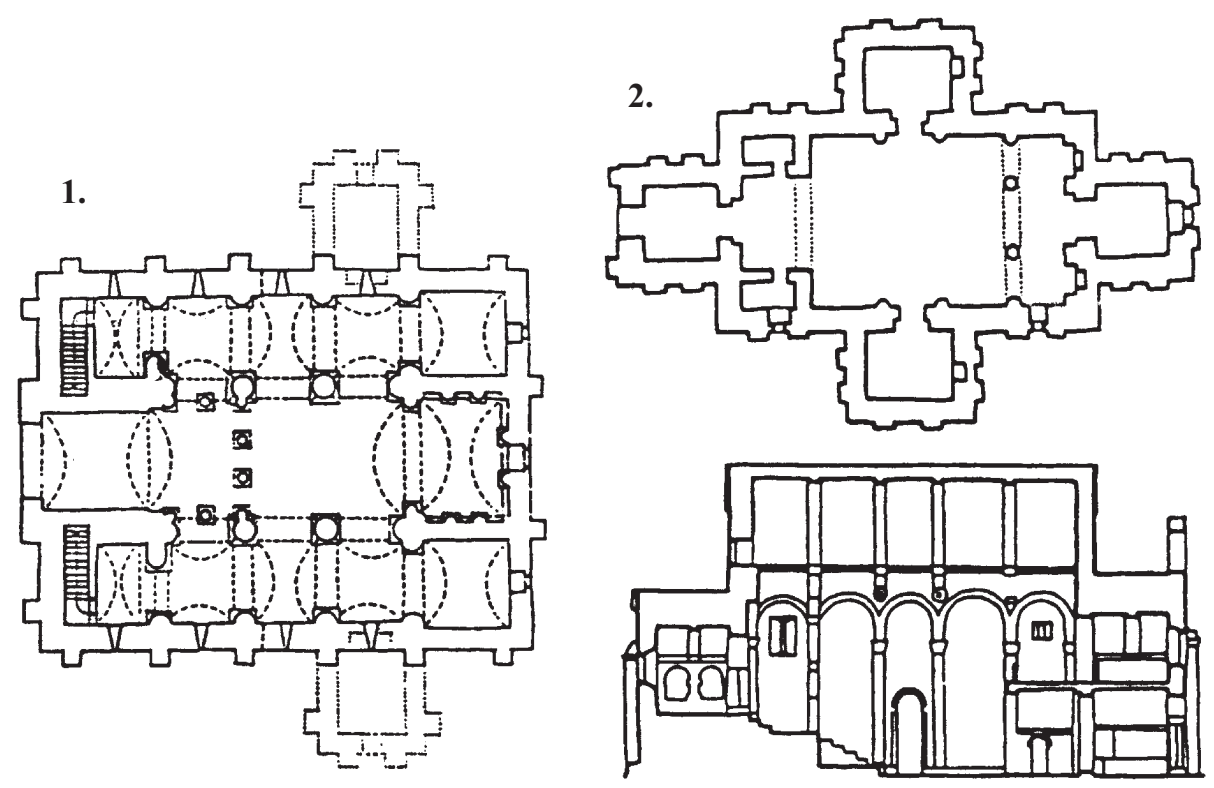

4. ábra. Hispániai Westwerk-megoldások: 1. Naranco, S. Miguel de Lillo,

2. S. Cristina de Lena 
megszüntetve a gallikán rítusok sokféleségét. ${ }^{14}$ Már 785-ben elkérte a római, 600 körül keletkezett Sacramentarium Gregorianumot, melynek szertartásrendjét a birodalma területén egységesen be akarta vezetni. A sors iróniája, hogy a könyv ravennai közvetítéssel, átiratban jutott el Aachenbe, számos - Ravennában használatossá vált - keleti elemmel. Így a frank birodalomban élő gallikán hagyományok és a szintén gallikán elemekkel bővült római (ravennai) Sacramentarium „,egymásra találtak" az egységesnek kikiáltott, de sokszínúségét megtartó frank-római liturgiában. A Verduni Szerződés (843) után felbomlott birodalom különböző részein más-más néven élt tovább ez a liturgia (fuzionált Gregorianum, lotharingiai rítus, rajnai miserend stb.), s benne a gallikán elemek - egészen az 1215-ös Lateráni Zsinat liturgikus változtatásáig.

1.

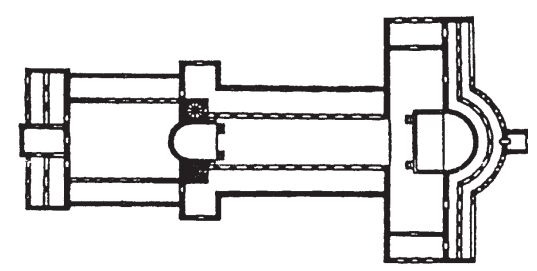

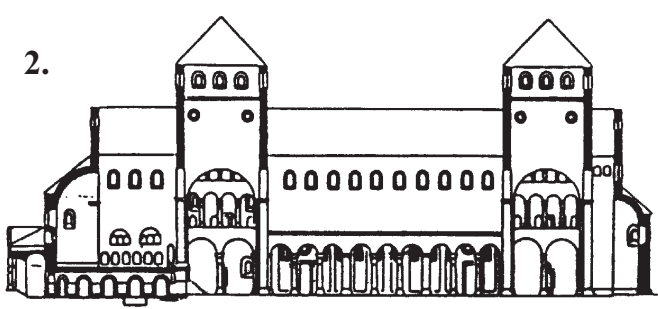

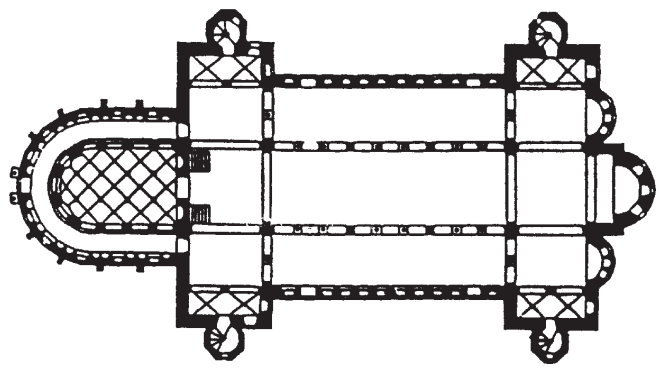

5. ábra. Kétszentélyes német templomok: 1. Fulda, apátsági templom, 2. Hildesheim, Szt. Mihály templom

A Westwerk összetett terében a húsvéti szertartások kiszolgálása mellett (vagy ahhoz kapcsolódva) lényegében két funkció ötvöződött: egy effektív szakrális térfunkció az emeleti kápolna révén és a kegyúri funkció (az alapító megkülönböztetett helye a templomban és halála után sírhelye a Westwerk földszintjén). Ennek megfelelően a Karoling-kor után a Westwerk továbbfejlődésében két tendencia érvényesült. Az egyik fejlódési vonalon a térrész szakrális jellegét domborították ki, s a Westwerk emeleti kápolnájából önálló nyugati szentély, nyugati kórus alakult

14 Félegyházy József: Az egyház a korai középkorban. Budapest, 1967. 433. old. 
ki. Az átmenetet jól szemlélteti a fuldai kolostortemplom (791-810), vagy a csak tervrajz-szinten ismert Sankt-Galleni kolostor (IX. sz.). Mindkettőnél megfigyelhető, hogy a Westwerk emelt terének kápolnája már apszidiális záródást kapott, $\mathrm{s}$ megnyílt a templomhajó felé. Az ezredforduló nagy kulturális és múvészeti központja, Hildesheim magáévá tette ezt az alapformát, s ezzel a német-római császárkori templomainak típusát teremtette meg. A hildesheimi Szt. Mihály templom (1010-1033) nyugati szentélye megőrizte a Westwerk kétszintes tagolását, az alsó részen körüljárós altemplommal, míg fölötte a Westwerk kápolna-tere önálló apszissá vált (5. ábra). Formai továbbélésként ezt a megoldást alkalmazták a XII-XIII. század nagy császári építkezéseinél (Mainz, Worms, Bamberg, Naumburg stb.) épp úgy, mint nagyobb szerzetesi templomoknál (Maria-Laach, Drübeck, Knechtsteden stb.). Érdekes módon nyugati szentélyek még akkor is épültek, amikor a liturgia már nem igényelte a Westwerk használatát (Worms Szt. Andráskórusa 1234-ben készült el - 20 évvel a Lateráni Zsinat liturgikus egységesítése után). Túl a hagyománytiszteleten és az egyszerü „divatjelenségen” ezeket a kései nyugati kórusokat szokták az ún. „kettős titulussal” is magyarázni: részben az egyházi naptárban azonos napon szereplő szentek (pl. Szt. Péter és Pál, Szt. Kozma és Damján, Szt. Perpetua és Felicitas, Szt. Fábián és Sebestyén stb.) ünnepével, részben a tudatos kettős titulus-választással (pl. Sz. Mária és Szt. Gotthard, Szt. Péter és Szt. Márton stb.). A konkrét példák ismeretében ez a feltevés nem igazolható. Valószínübb, hogy a Westwerket idéző nyugati szentély a halotti istentiszteleti funkció továbbélésével függ össze. Ennek viszont távoli gyökerei és előzményei mutathatók ki. Az egyiptomi és a núbiai korai templomoknál gyakori, hogy nincs nyugati kapu, hanem a főhajó nyugati végében egy egyenes lezárású quasiapszis alakul ki, a mellékhajók vonalában két melléktérrel (Kagerasz, Farasz, VI-VIII. sz., Szahaba, Abdallah-Nirqi, IX-X. sz.). ${ }^{15}$ Szahaba és Abdallah-Nirqi esetén az ásatás kimutatta, hogy ebben a nyugati térben sírhely vagy halotti oltár állt (6. ábra). Észak-Afrikában más kétapszisos ókeresztény templomok is ismertek, pl. Orléansville (Algéria, V. sz.), Sabrata (Líbia, 450 után), Leptis Magna (Líbia, 550 körül) stb. Ezeket azonban nem vonhatjuk be ebbe a vizsgálati körbe: valamennyi felsorolt templom korábbi, római épület (bazilika, fórum) átépítésével vált keresztény templommá, így a keleti-nyugati apszidiális bővület adottság volt, s nem a liturgia követelményéből született ${ }^{16}$.

A Westwerk továbbélésének másik iránya bizonyos „elcsökevényesedés”, amikor is a nyugati többszintes tér csupán a két toronyra és a köztük lévő karzatra zsugorodik. A nyugati karzatot szokták kegyúri karzatnak is nevezni, utalva arra,

15 Gartkiewicz, Przemyslav M.: New outline of the history of Nubian church architecture. BABesch 55, 1980/1, 137-160. old.

16 Guzsik Tamás: Szakrális épitészeti terek funkcióelemzése, I. Budapest, 1988. 49-51. old. 
1.

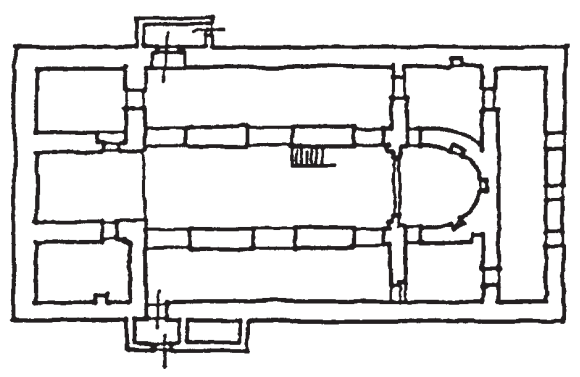

2.

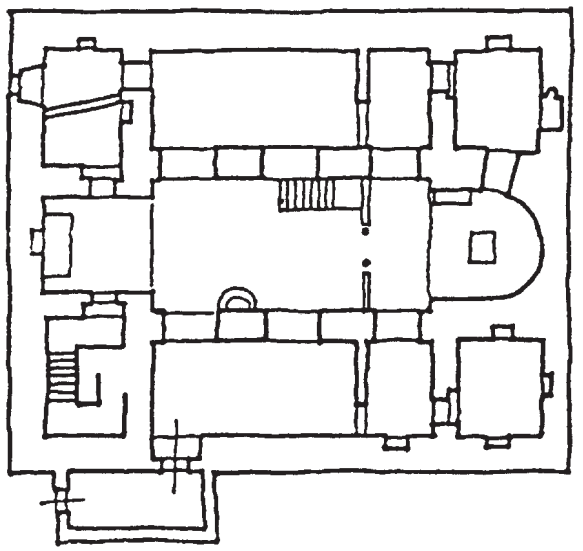

6. ábra. Núbiai templomok nyugati, „halotti” szentéllyel: 1. Szahaba, 2. Abdallah-Nirqi

hogy ebben a fejlődési vonalban a nyugati építménynek elsősorban a kegyúri reprezentációval kapcsolatos szerepe domborodik ki. A nyugati kapu két toronyszerü építménnyel, pilonnal történő kiemelése a szír ókeresztény építészetben általános volt. A tornyok között a földszinten nyitott kapucsarnok volt (livan), az emeleti karzat is kifelé nyílt, a templomtérrel nem volt kapcsolatban (Turmanin, QalbLuzeh, 460-480 körül). A nők elkülönítésére szolgáló karzatok (emporium) a mellékhajók fölött húzódtak, ezek a templomtérbe nyíltak. A szír missziók nyomán az V. századtól elterjedt egy olyan templomtípus, ahol a kapu melletti két „torony” földszintje és a nyugati előcsarnok már szerves egységet alkotott. Az így létrejövő hármas térrész ismét csak a halotti szertartásokkal hozható kapcsolatba (Egyiptomban El-Ghazali, Old-Dongola, Farasz, Qasr-Ibrim, Nuri, Tamit, Amalika stb., VI-VIII. sz., Etiópiában Axum, Lalibela, Abba Libanosz, V-VI. sz. stb.). ${ }^{17}$ Az örmény templomokban (pl. Avan, Hripszime, Szisszavan, Targmancsazvank stb.) a VII. századtól szintén az ereklyekultusszal és a halottkultusszal kapcsolatban építettek ilyen tércsoportokat (zsamatun). ${ }^{18}$ A nyugati karzatnak, empóriumnak a középkori, nyugati rítus szerinti templomokban külön funkciója nem volt, orgonakarzatként csak a középkor késői szakaszában használták őket. A kegyúri alapítású templomnál viszont alkalmasak voltak arra, hogy a Westwerk kegyúri funkcióját redukált formában tovább folytassák. A normandiai Jumiéges apátsági templomában a felszenteléskor (1067) Hódító Vilmos elkülönített uralkodói helye a nyugati

17 Kunst und Geschichte Nubiens in Christlicher Zeit. Recklinghausen, 1970, ill. Linahl, Bernhard: Architectural History of Ethiopia in Pictures. Addis-Ababa, 1970.

18 Guzsik Tamás: Gavit és zsamatun. Épités- Épitészettudomány, 26, 1996/1-2, 131-163. old. 
karzaton volt, s ez az elrendezés típusalkotóvá vált a későbbi kegyúri templomoknál. Szintén a Westwerk redukciójaként a karzaton, vagy ahhoz kapcsolódva kegyúri magánkápolna is volt. A templomon belüli ilyen elkülönítés kiteljesedve a várés palotakápolnáknál jelentkezik: a kétszintes templom alsó része a köznép, az emelete a kegyúri család helye, a két szint között csak egy aknaszerủ nyílás van középen (pl. Schwarz-Rheindorf, püspöki kápolna, 1151, Mainz, érseki palotakápolna, 1130 körül, Nürnberg, palotatemplom, 1220 körül stb.) ${ }^{19}$ (7. ábra).

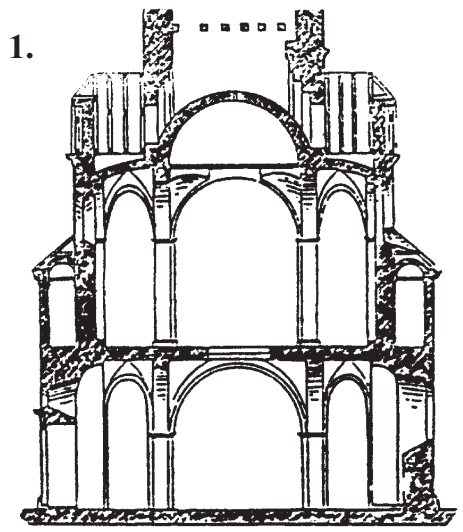

2.
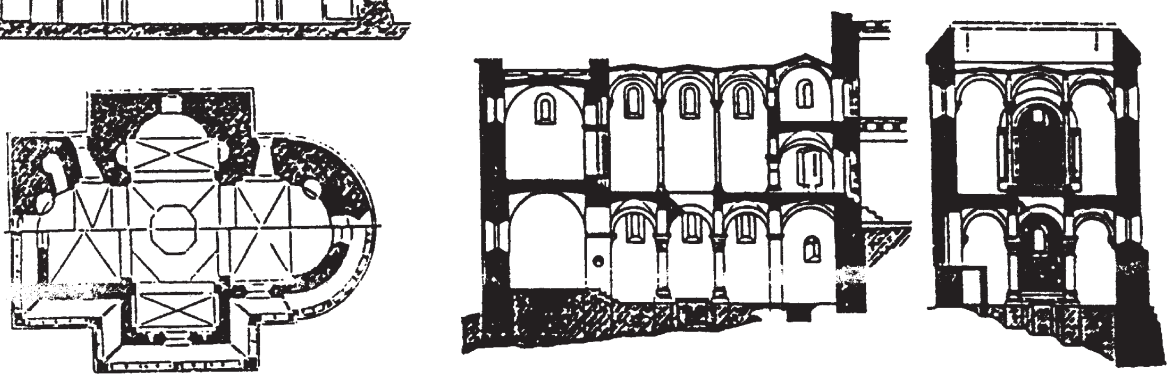

7. ábra. Kétszintes palotakápolnák: 1. Schwarz-Rheindorf, püspöki kápolna, 2. Nürnberg, palotakápolna

A magyar egyházszervezés korában - a fennmaradt források szerint - többnyire az ún. „rajnai miserendet” követte a székesegyházak és a monostorok legtöbbje. Furcsa módon az ismertetett kétszentélyes (vagy Westwerkes) templomtípus nem terjedt el Magyarországon. Feltárásokból mindössze két helyen tudunk nyugati szentélyrôl, Pannonhalmán és Szer-monostoránál (Pusztaszer) - utóbbi esetben a feltárást vezető Trogmayr Ottó régész közvetlen St. Gallen-i kapcsolatot feltételez. Zselicszentjakab korai (1061) nemzetségi monostoránál a nyugati oldalon sejthető

19 Guzsik Tamás: Középkori építészettörténeti ábraanyag, II. Budapest, 1994. 42. tábla. 
egy Westwerkre emlékeztető karzatos építmény, de erről hiteles rekonstrukció eddig nem készült. A későbbi, XIII. századi nemzetségi alapítású monostorok mindegyike nyugati, kegyúri karzattal épült. Több helyen kimutatható, hogy a karzaton önálló oltár is volt. A jáki bencés apátság templomában (1220 körül-1256) a karzat mellvédjén, a kegyúri ülésekkel szemben egy konzolon állt a kis oltár, Zsámbékon (1220 körül-1258) a déli torony emeleti helyisége volt a kápolna, a kegyúri karzat felől betekintő nyílással. Utóbbi esetben sajnos a folyó helyreállítás során ezt a tényt figyelmen kívül hagyták! A Westwerknek a halotti szertartásokkal kapcsolatos funkciója többször önálló, a monostortemplomtól nyugatra (vagy északra) álló centrális kápolna formájában valósult meg (Ják, Boldva, Zselicszentjakab, Kisbény stb.).

A Westwerk kései és redukált változata maradt meg a felsőőrsi társaskáptalani (prépostsági) templomban, ahol a toronyemelet Szt. Mihály (!) kápolnáját 1240 körül szentelte föl Bertalan veszprémi püspök. ${ }^{20} \mathrm{~A}$ vaskos torony földszintjén a lépcsőtér alatt kegyúri sírfülke volt, a toronyemelet két helyiségből állt. Egyik része volt a kegyúri karzat, mely ívezettel nyílt a hajóba, míg a másik, zárt helyiségben szentségőrző fülke volt. Ez a elrendezés megfelel a Westwerk követelményeinek, csupán anakronisztikus: a liturgiát szabályozó Lateráni Zsinat után 15 évvel miért építettek egy 2-300 évvel korábbi liturgiának megfelelő teret? Szinte azonos szituáció van a csallóközi Csütörtök (Stvrtok na Ostrove) egykori ,,fertály-káptalani” templomában (1250 körül épült ki a jelenlegi nyugati rész). Itt a kéttornyos nyugati oldal emelete, a karzatszint a hajó felé teljesen zárt volt, a hajóból felvezető lépcső emeleti kapuját 1976-ban sikerült feltárnunk. Az emelet egykori diszpozíciója itt is kápolna létére utal, sajnos a szentségőrző fülkét nem tudtuk azonosíta$\mathrm{ni}^{21}$

A XIII. század során épült, nemzetségi alapítású parochiális egyházaknál viszonylag gyakran találkozunk olyan torony- ill. karzatkialakítással, mely az egykori Westwerk-funkciót idézi. Alsódörgicsén a hajószélességü toronytest emelete, Zobor-Darázsban (Drazovce) és Nagytoronyán (Velká Torona) a karzat-rész a hajó felé teljesen zárt, csupán néhány ablakkal kapcsolódik a hajóhoz. Zalaszentmihályfán, Szőcén, Kustányban, Csarodán, Fényeslitkén stb. a hajó terébe benyúló toronytest emelete jelent zárt egységet. A nyugat-oldali építmények funkcionális és tipológiai vizsgálatában egy nem elhanyagolható „oldalág” a XIII. századi alapítású szász templomok toronymegoldása. Az egyetlen homlokzati középtorony az egyhajós templomoknál a hajóval azonos szélességü, a háromhajós változatban a torony a főhajó szélességében, annak nyugati része fölött magasodik. Néhány is-

20 Erdei Ferenc: Felsőörs, prépostsági templom. TMK 118. Budapest, 1982.

21 Guzsik, Tamás: Die mittelalterliche Baugeschichte der Kirche von Csütörtök. Acta Technica $88,1979 / 1-4,303-329$. old. 
mertebb példa: Nagysink (Cincu, Grosschenk), Nagydisznód (Cisnădie, Heltau), Morgonda (Merghindeal, Mergeln), Baromlak (Valea Villor, Wurmloch), Ecel (Ațel, Hetzeldorf), Szászhermány (Harman, Honigberg) stb. ${ }^{22}$ A példák mindegyikénél a torony emelete kapcsolatban van a templomhajóval, quasi nyugati karzatként vagy emeleti kápolnaként. A települések jogállását figyelembe véve a kegyúri funkció nem jön szóba, az egykori szakrális tér-jelleg (Westwerk) pedig már nem bizonyítható. A XV. századtól kezdve ezeknek a templomoknak a legtöbbjét megerősítették, s maga a templom is a védelmi rendszer része lett (erődtemplom). Éppen a torony, annak fölső, emeleti része vált a védelmi rendszer központjává, így a legtöbb militáris jellegú átalakítást itt végezték. De azt sem szabad elfelejteni, hogy az erdélyi szász terület lakossága a XVI. századtól a lutheri reformációt követte, $\mathrm{s}$ a meglévő templomokat az evangélikus liturgia követelményeinek megfelelően alakították át. Ebben pedig sem a húsvéti, sem a halotti szertartások kápolnáinak nem volt létjogosultsága, s néhány generáció után az eredeti funkciónak még az emléke is eltünt. A csak ötletszerúen kiválasztott és felsorolt XIII. századi példák felvetik annak a lehetőségét, hogy a XIII. század elején (1215) foganatosított liturgikus egyszerüsítések a magyar gyakorlatban csak nagyobb késéssel valósultak meg, s egyes helyeken még a század közepén, sőt a második felében is végezték a korábbi, Karoling hagyományokra visszavezethető „rajnai” liturgiát. Mindez a liturgia más területein már korábban is bebizonyosodott, hiszen a gallikán liturgiákban általános „előmisét” (proszkomidia) a magyar-római szertartásrendben 1632-ig kimutathatóan végezték, ${ }^{23}$ sőt egyes dominikánus közösségekben még a XX. században is szokásban volt.

A liturgiatörténet és a szakrális építészet kapcsolatában kétségtelenül nem elsődleges, de mégsem elhanyagolható a most felvázolt probléma: a kelet-oldali szentély ellenpólusaként, a templom nyugati felében végzett szertartások rendje és azok építészeti kerete. A témára immár harmadszor visszatérő jelen tanumány sem vállalkozhatott arra, hogy az időközben felmerült kérdésekre kimerítő és lezárható feleletet adjon. Talán csak a kérdésfelvetés és -megközelítés terén próbált új utakat keresni, amennyiben a különböző keleti és nyugati középkori liturgia-csoportok szertartásaiban meglévő közös elemeket próbálta néhány adott építészeti térforma, a Westwerk, a nyugati kórus (szentély) és a nyugati karzat vizsgálatában összekapcsolni és egymásnak megfeleltetni.

22 Hermann und Alida Fabina: Kirchenburgen in Siebenbürgen. Leipzig, 1985, Szentpétery

Tibor-Kerny Terézia: Az Olttól a Küküllöig. Budapest, 1990.

23 Radó Polikárp: A megújuló istentisztelet. Budapest, 1973. 57. old. 
